\title{
uSocial REALTIME BERBASIS ANDROID MENGGUNAKAN VOLLEY DAN ALGORITMA BRUTEFORCE
}

\author{
Azizah $^{1}$, Fauziah $^{2}$, Nur Hayati ${ }^{3}$ \\ Informatika, Fakultas Teknologi Komunikasi dan Informatika, Universitas Nasional ${ }^{1,2,3}$ \\ azizahif99@gmail.com ${ }^{1 *}$, fauziah@ @ivitas.unas.ac.id ${ }^{2}$, nurhayati@ civitas.unas.a.c.id ${ }^{3}$
}

Submitted October 28, 2020; Revised November 25, 2020; Accepted November 27, 2020

\begin{abstract}
Abstrak
Komunikasi dapat dilakukan dimana saja dan kapanpun sehingga mempermudah masyarakat untuk bertukar informasi. Berkomunikasi saat ini sangat mudah dengan memanfaatkan beragam aplikasi atau media dengan menggunakan fasilitas internet yaitu aplikasi seperti Instagram, Facebook, WhatsApp Messenger dan lainnya. Aplikasi uSocial dapat menghubungkan pengguna dalam berkomunikasi, bertukar informasi dan berbagi ilmu yaitu aplikasi uSocial. Aplikasi ini dibuat dengan menerapkan metode Firebase, Volley dan RecyclerView. Ketiga metode tersebut berguna untuk menjalankan aplikasi secara langsung atau Real-time. Pengujian algoritma dilakukan dengan membandingkan algoritma Brute Force dengan algoritma Horspool dan Knuth Morris Pratt. Hasil dari pengujian algoritma Brute Force pada pencarian kata dilakukan berdasarkan panjangnya kalimat pencarian menghasilkan akurasi sebesar $100 \%$ untuk uji coba 500 data serta mempersingkat waktu untuk pencarian postingan maka lebih baik menggunakan algoritma Brute Force. Pada hasil pengujian menggunakan metode whitebox yang diuji menggunakan 3 parameter yaitu cyclomatic complex city, region, dan independent path menghasilkan nilai yang sama sebesar 17. Maka alur dan logika program sudah sesuai dengan standar ANSI dan tidak perlu mengubah alur atau program kembali. Sedangkan hasil pada pengujian blackbox, fungsi-fungsi yang ada pada aplikasi menghasilkan output yang diinginkan.
\end{abstract}

Kata kunci: Android, Firebase Real-time, Media sosial, Aplikasi, Bruteforce.

\begin{abstract}
Communication can be done anywhere and anytime, making it easier for people to exchange information. Communicating today is very easy by utilizing various applications or media by using internet facilities such as Instagram, Facebook, WhatsApp Messenger, and others. The author builds an application that can connect users in communicating, exchanging information, and sharing the science that is the uSocial application. The app is created by applying the Firebase, Volley, and RecyclerView methods. These three methods are useful for running applications directly or In Realtime. Algorithm testing is done by comparing the Brute Force algorithm with the Horspool, and Knuth Morris Pratt algorithms. The results of Brute Force algorithm testing on word searches performed based on the length of search sentences resulting in 100\% accuracy for 500 data trials as well as shortening the time for posts searches then better using Brute Force algorithms. The test results using the Whitebox method tested using three parameters, namely cyclomatic complex city, region, and independent path, produce 17. The program's flow and logic follow ANSI standards and there is no need to change the flow or plan back. At the same time, the results on the Blackbox testing of the functions in the application managed to produce the desired output.
\end{abstract}

Keywords: Android, Firebaes Real-time, Social media, Apps, BeruteForce

\section{PENDAHULUAN}

Komunikasi memainkan peran yang sangat penting untuk berinteraksi dengan yang lainnya. Dewasa ini berkomunikasi dapat memanfaatkan beragam aplikasi atau media, kalangan masyarakat tidak asing dengan smartphone yang dapat menghubungkan satu sama lain dengan menggunakan fasilitas internet dan aplikasi seperti WhatsApp Messenger, Instagram, Facebook dan lainnya. Android merupakan sistem operasi untuk ponsel yang dikem- 
bangkan oleh Google. Firebase merupakan database yang menggunakan soket yang memungkinkan pengguna untuk menyimpan dan mengambil data dari database [1]. Push notification merupakan layanan yang digunakan untuk pemberitahuan melalui pesan yang ada di smartphone [2]. Dalam layanan ini pemberitahuan atau notifikasi dilakukan secara langsung (Real-time) yang mempermudah pengguna dalam menerima informasi atau data yang diperlukan. Volley merupakan library yang digunakan untuk pertukaran data dari server dengan client dengan lebih mudah dan cepat [3].

Media daring yang digunakan pengguna agar berpartisipasi dengan mudah biasa disebut dengan media sosial [4]. Fitur di berbagai media sosial sangat bervariasi diantaranya berbagi pengalaman, berbagi postingan, pesan dan masih banyak lagi. Penelitian yang dilakukan oleh [5] adalah membuat aplikasi media sosial dengan membuat fitur pesan. Pada hasil penelitian yang dilakukan oleh [6] pada tahun 2018 yaitu mengimplementasikan menu pesan dan pengingat tugas. Pada penelitian yang dilakukan oleh [7] mengimplementasikan Algoritma AES pada aplikasi media sosial yang menerapkan fitur beranda dan menu pesan. Pada penelitian yang dilakukan oleh [8] pada tahun 2017 membuat aplikasi media tanya jawab dengan menerapkan membagikannya ke pengguna melalui fitur beranda secara langsung. Kemudian pada penelitian yang dilakukan oleh [9] pada tahun 2018 yang mengimplementasikan fitur notifikasi. Penelitian yang dilakukan oleh [10] pada tahun 2019 membuat aplikasi media sosial yang dapat membuat postingan dan chat messenger [10].

Pada penelitian ini, penulis menerapkan volley dan algoritma bruteforce pada aplikasi uSocial. Pada penelitian sebelumnya aplikasi media sosial belum menerapkan keseluruhan menu di dalam aplikasi yang telah dibuat, penulis bermaksud untuk melakukan perbaikan dengan membuat menu pesan, postingan, push notifications, notifikasi komentar, suka pada postingan, dan fitur mencari postingan secara langsung. Aplikasi uSocial merupakan aplikasi media sosial berbasis Android dengan menu yang mudah digunakan dan dapat digunakan pada smartphone android tanpa menggunakan media komputer lain ataupun website untuk saling terhubung satu sama lain baik komunitas, individu ataupun alumni untuk berbagi informasi dan komunikasi.

\section{METODE PENELITIAN}

Metode penelitian dilakukan dalam beberapa tahap yaitu studi literatur, perumusan masalah, pengembangan sistem dan penarikan simpulan. Kumpulan kegiatan mengenai metodologi pengumpulan data acuan, membaca, mencatat dan mengolah bahan yang akan dilakukan penelitian disebut dengan studi literatur [11]. Dapat mengungkapan teori yang tepat dengan permasalahan yang sedang diteliti sebagai bahan acuan pembahasan penelitian. Perumusan masalah memperjelas masalah sehingga mempermudah dalam menyelesaikannya. Dari hasil studi literatur, penulis menemukan permasalahan yang dapat dirumuskan yaitu, bagaimana membangun aplikasi uSocial dengan menerapkan algoritma bruteforce dan beroperasi secara langsung. Tahap pengembangan sistem memakai metode air terjun atau waterfall dengan tahapan yang dapat dilihat pada gambar 1 [12].

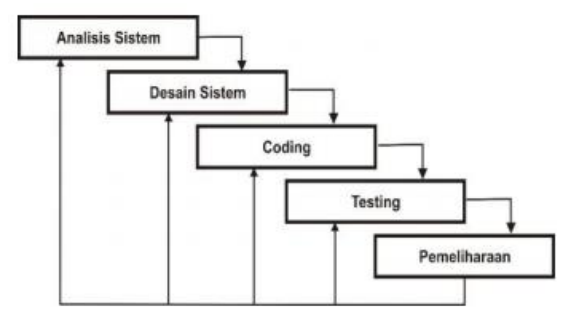

Gambar 1. Metode Waterfall 
Untuk mencapai target suatu aplikasi dengan cara mendesain aplikasi untuk memeriksa apakah mencapai kebutuhan atau tidak [13]. Pengembangan sistem dengan melakukan Analisa kebutuhan sistem, desain, pembuatan program dan pengujian aplikasi.

\section{Analisa Kebutuhan Sistem}

Analisis sistem didefiniskan sebagai proses dalam mengumpulkan, menginterpretasikan kenyataan, mendiagnosa permasalahan dan menyatukannya untuk memperbaiki system [14]. Kebutuhan sistem yang diperlukan dalam membuat aplikasi ini yaitu:

1. Perangkat Keras (Hardware)

Perangkat keras pada penelitian kali ini terdiri dari :

- Laptop (ASUS VivoBook A442U) dengan spesikasi sebagai berikut
a. CPU Intel Core i5 8th Gen
b. RAM 8GB DDR4
c. NVDIA 930MX
d. HDD 1TB

2. Perangkat Lunak (Software)

Perangkat lunak yang digunakan pada penelitian terdiri dari :

- Android Studio 3.4

-Windows 1064 bit (Sistem Operasi)

\section{Desain sistem}

Pada aplikasi uSocial memiliki fitur yang dapat dilihat pada pada use case diagram sebagai berikut:

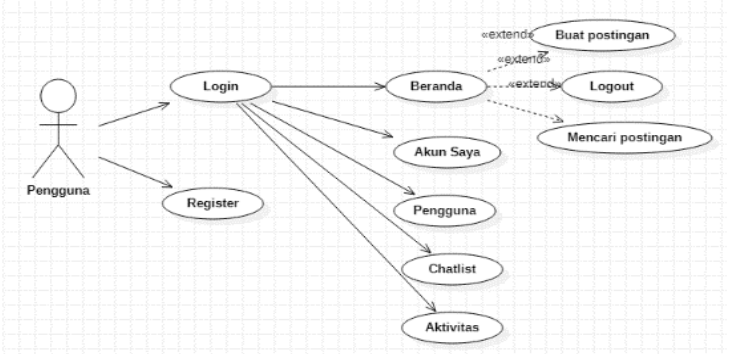

Gambar 2. Use case Diagram Aplikasi uSocial
Pada gambar 2 menjelaskan pengguna dapat mengakses aplikasi uSocial dengan melakukan register dan login. Setelah masuk kedalam aplikasi pengguna dapat membuat postingan, berkomunikasi melalui chat messenger, mendapatkan notifikasi jika pengguna lain menyukai dan berkomentar pada postingan yang dibuat.

\section{Pengkodean (coding)}

Aplikasi uSocial ini menerapkan Bahasa pemrograman Java Android dengan mengimplementasikan POJO menggunakan Volley dalam mengambil dan mengirimkan data dan RecyclerView dalam menampilkan postingan, isi pesan dan chatlist. Selanjutnya algoritma Brute Force yang diimplementasikan dalam membandingkan string dengan tiap karakter. Proses yang dilakukan yaitu membandingkan karakter dimulai dari kiri ke kanan secara berulang sampai menemukan kecocokan antara string dan teks [15].

\section{Pengujian (Testing)}

Blackbox dan whitebox merupakan metode yang digunakan untuk pengujian aplikasi uSocial.

\section{Pemeliharaan}

Aplikasi ini akan dilakukan perbaikan setelah adanya evaluasi dari pengguna dengan tujuan agar aplikasi lebih menarik lagi.

\section{HASIL DAN PEMBAHASAN}

Aplikasi uSocial ini mengimplementasikan Firebase Authentication pada saat pengguna mendaftarkan akun dan masuk kedalam aplikasi uSocial. Kemudian mengimplementasikan Firebase Database Realtime yang digunakan untuk menyimpan dan mengirimkan data yang diperlukan pengguna. Menerapkan notifikasi dan pesan bisa menggunakan Cloud Messaging. Untuk menyimpan data foto yang diunggah oleh pengguna menggunakan Firebase Storage. 


\section{Struktur database}

Aplikasi uSocial memiliki struktur database yaitu tokens, users, chatlist, postss, dan chats. Pada child users berisi data akun pengguna yang terdaftar, child tokens berisi token untuk masuk kedalam aplikasi yang dibaca oleh sistem agar selalu terkoneksi dengan database. Tokens ini dibuat pada saat pengguna memasang aplikasi dan mendaftarkan akun pertama kali pada aplikasi uSocial. Data pesan yang dikirimkan oleh pengguna disimpan dalam child chats, child chatlist diinisialisasikan untuk menyimpan pesan terakhir dan menampilkannya di menu chatlist, dan child postss berisi data yang tersimpan oleh pengguna ketika membuat tulisan atau mengunggah gambar di home. Gambar 3 merupakan struktur database aplikasi uSocial.

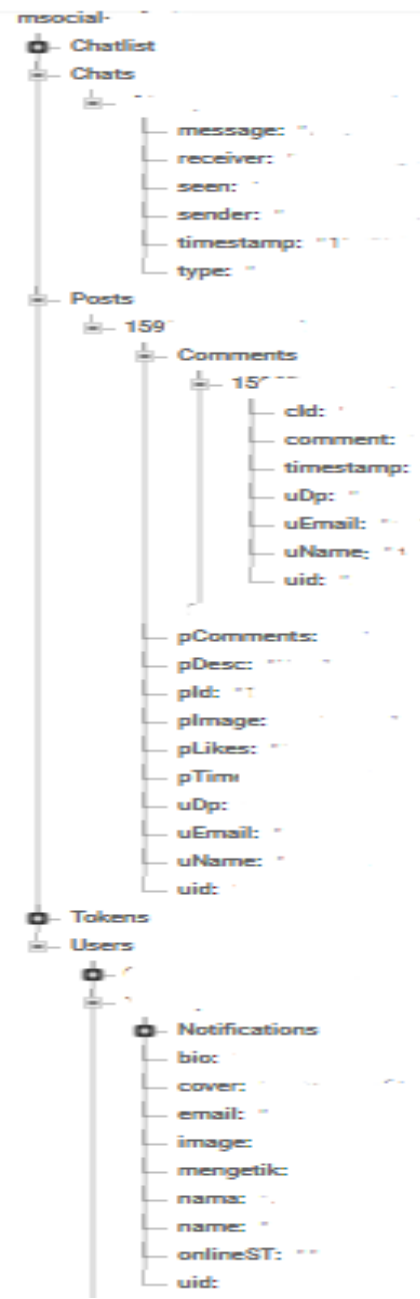

Gambar 3. Struktur Database

\section{Struktur Aplikasi}

Aplikasi uSocial menggunakan struktur aplikasi yaitu client-server, dimana pengguna dapat mengakses data bersamaan dengan server.

\section{Client}

Database Firebase diintegrasikan pada aplikasi uSocial untuk menyimpan serta menampilkan data pengguna secara langsung pada aplikasi.

\section{Server}

Server bersifat langsung (Realtime) yang artinya jika ada perubahan data pada aplikasi maupun server otomatis akan ter-update pada perangkat pengguna.

\section{Algoritma yang digunakan}

Firebase Authentication diterapkan pada aplikasi uSocial agar pada saat membuat akun, data yang disimpan terenkripsi dan aman sehingga tidak ada yang mengetahui kata sandi pengguna dengan menggunakan algoritma seperti ini.

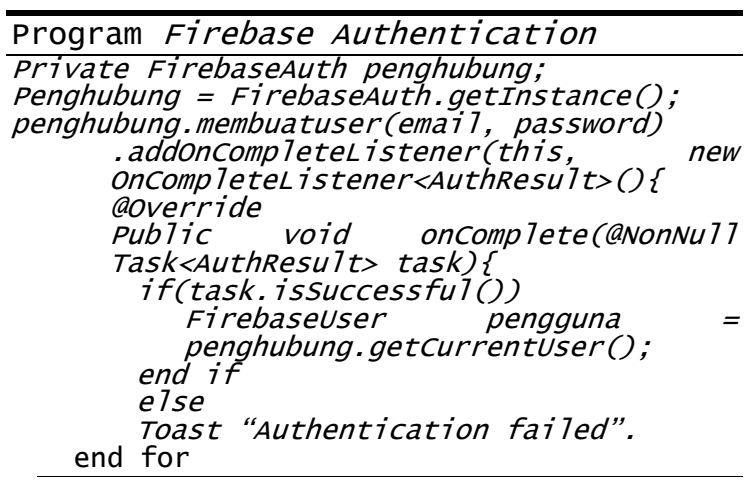

Pada algoritma program yang digunakan untuk membuat akun pengguna menggunakan Method penghubung yang memprogram jika berhasil mendaftarkan akun maka pengguna langsung masuk kedalam aplikasi. Namun jika gagal maka akan tampil pesan error.

Volley digunakan untuk mengambil data dari client-server kemudian menampilkan notifikasi pada perangkat pengguna pada saat mengirimkan atau menerima pesan dengan struktur sebagai berikut. 


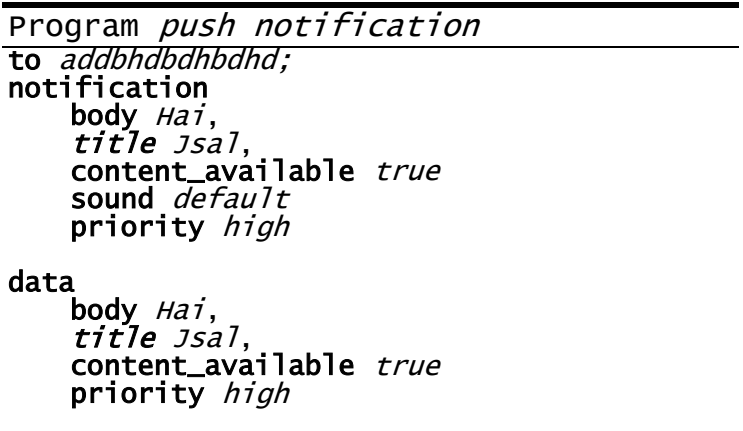

Program push notification mengeluarkan output berupa notifikasi yang diterima pengguna.

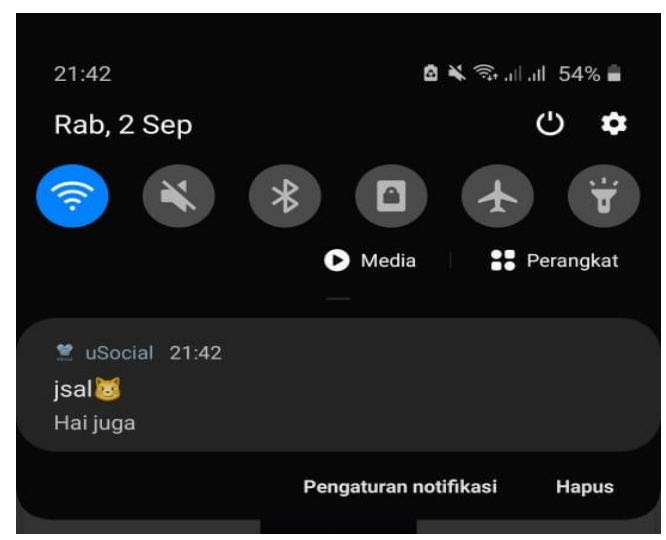

Gambar 4. Tampilan Notifikasi Pesan

Hasil output dari program push notification dapat dilihat pada gambar 4 .

\section{Tampilan Aplikasi}

Tampilan aplikasi ini dibuat menggunakan pemrograman XML serta mengimplementasikan struktur Model-View dan ditampilkan menggunakan fitur RecyclerView. Tampilan keseluruhan aplikasi uSocial dapat dilihat pada gambar 5 .

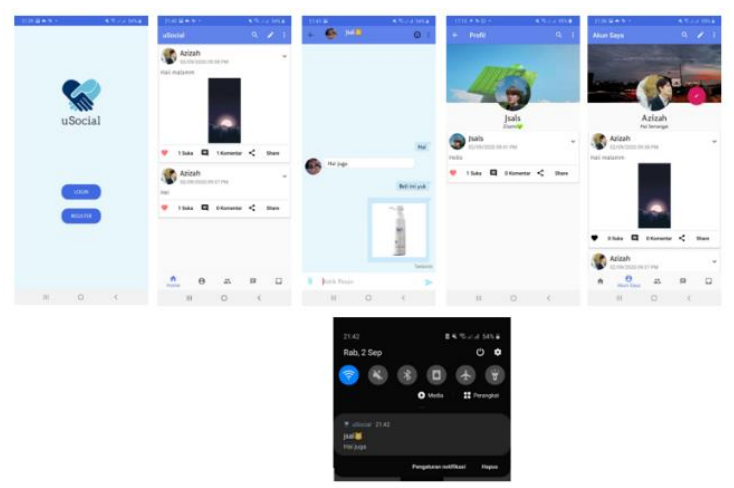

Gambar 5. Tampilan Aplikasi
Aplikasi uSocial memiliki menu login dan register yang betujuan untuk mendapatkan akun. Selain menu login aplikasi ini memiliki fitur menu akun saya, home, pesan, aktivitas dan pengguna. Aplikasi ini mengimplementasikan fitur push notification pada saat pengguna mengirimkan pesan sehingga pengguna lain dapat menerima notifikasi diperangkatnya.

\section{Penerapan Algoritma bruteforce}

Penerepan algoritma bruteforce yaitu pada saat mencari isi atau konten postingan, fitur pencarian ini dibuat untuk mempermudah pengguna dalam mencari konten pengguna lain dengan mudah.

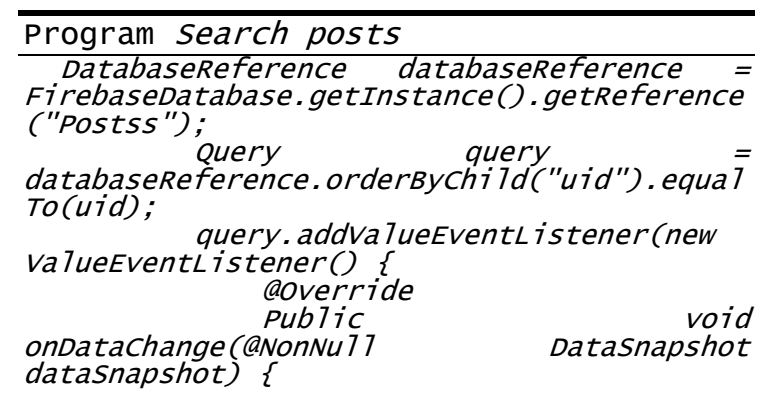
datapostsList.clear();
for (Datasnapshot ds: datasnapshot.getChi7dren()) Dataposts dataposts = ds.getva7ue (Dataposts. Class); if

(dataposts.getpDesc(). tolowerCase (). contain $s$ (searchqueku. tolowercase ()) ) \{

datapostsList.add(dataposts);

\}

adapterposts $=$ new Adapterposts(getactivity(), datapostsList); postsrv.setAdapter(adapterposts);

$$
\}
$$

Program search posts ini diterapkan pada menu home, akun saya dan pengguna. Tujuan membuat program ini memudahkan pengguna yang ingin mencari pengguna lain atau postingan yang menarik dengan mudah. 


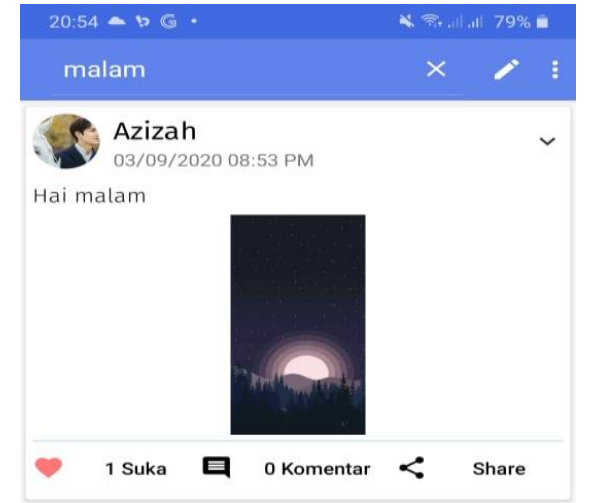

\section{Gambar 6. Fitur Mencari Postsing}

Pengguna mencari postingan yang berdeskripsi kata "Hai malam" dengan string "malam" terlihat pada gambar 6 . Langkah pertama dalam implementasi algoritma Bruteforce pada pencarian string "malam" dapat dilihat pada tabel 1.

\section{Tabel 1. Langkah 1}

\begin{tabular}{l|lllllllllll|} 
Deskripsi & H & a & i & & m & a & 1 & a & $m$ & \\
\multirow{2}{*}{ String } & m & a & 1 & a & m & & & & & \\
& & & & & & & & & & & \\
Indeks & 0 & 1 & 2 & 3 & 4 & 5 & 6 & 7 & 8
\end{tabular}

Pada tabel 1 melakukan pencocokan karakter pertama antara string dengan deskripsi. Bila belum menemukan kecocokan maka tetap melakukan proses pencocokan.

Tabel 2. Langkah 2

\begin{tabular}{l|lllllllllll} 
Deskripsi & H & a & i & & m & a & 1 & a & $m$ \\
String & & m & a & 1 & a & m & & & & & \\
& & & & & & & & & & & \\
Indeks & 0 & 1 & 2 & 3 & 4 & 5 & 6 & 7 & 8
\end{tabular}

Tabel 2 terlihat bahwa karakter a tidak cocok dengan karakter m maka dilanjutkan ke proses pencocokan berikutnya.

\section{Tabel 3. Langkah 3}

\begin{tabular}{l|llllllllll} 
Deskripsi & H & a & i & m & a & 1 & a & m \\
String & & & & m & a & 1 & a & m & & \\
& & & & & & & & & & \\
Indeks & 0 & 1 & 2 & 3 & 4 & 5 & 6 & 7 & 8
\end{tabular}

Tabel 3 terlihat bahwa karakter i tidak cocok dengan karakter m maka dilanjutkan ke proses pencocokan berikutnya.

Tabel 4. Langkah 4

\begin{tabular}{l|lllllllllll} 
Deskripsi & H & a & i & & m & a & 1 & a & $m$ \\
String & & & & m & a & 1 & a & m & & \\
& & & & & & & & & & & \\
Indeks & 0 & 1 & 2 & 3 & 4 & 5 & 6 & 7 & 8
\end{tabular}

Pada tabel 4 terlihat bahwa karakter " " atau spasi tidak cocok dengan karakter $m$ maka dilanjutkan ke proses pencocokan berikutnya.

Tabel 5. Langkah 5

\begin{tabular}{|c|c|}
\hline Deskripsi & $\begin{array}{llllllll} & \mathrm{a} & \mathrm{i} & \mathrm{m} & \mathrm{a} & \mathrm{l} & \mathrm{a} & \mathrm{m}\end{array}$ \\
\hline String & $\mathrm{m}$ a 1 a $\mathrm{m}$ \\
\hline
\end{tabular}

Pada tabel 5 antara deskripsi dengan string mengalami kecocokan di indeks ke-4 maka tidak melakukan pergeseran kembali.

Tabel 6. Hasil Pengujian Akurasi Algoritma Bruteforce pada Deskripsi dengan String

\begin{tabular}{|c|l|l|c|}
\hline No & \multicolumn{1}{|c|}{ Input } & \multicolumn{1}{c|}{ Output } & Hasil \\
\hline 1 & orang-orang & orang-orang & $100 \%$ Akurat \\
\hline 2 & Sejarah & sejarah & $100 \%$ Akurat \\
\hline 3 & Cara & cara & $100 \%$ Akurat \\
\hline 4 & Seni & seni & $100 \%$ Akurat \\
\hline 5 & Dunia & dunia & $100 \%$ Akurat \\
\hline 6 & Informasi & informasi & $100 \%$ Akurat \\
\hline 7 & Peta & peta & $100 \%$ Akurat \\
\hline 8 & Dua & dua & $100 \%$ Akurat \\
\hline 9 & Keluarga & keluarga & $100 \%$ Akurat \\
\hline 10 & Pemerintah & pemerintah & $100 \%$ Akurat \\
\hline 11 & kesehatan & kesehatan & $100 \%$ Akurat \\
\hline 12 & sistem & sistem & $100 \%$ Akurat \\
\hline 13 & komputer & komputer & $100 \%$ Akurat \\
\hline 14 & daging & daging & $100 \%$ Akurat \\
\hline 15 & tahun & tahun & $100 \%$ Akurat \\
\hline 16 & $\begin{array}{l}\text { Terima } \\
\text { kasih }\end{array}$ & $\begin{array}{l}\text { Terima } \\
\text { kasih }\end{array}$ & $100 \%$ Akurat \\
\hline 17 & musik & musik & $100 \%$ Akurat \\
\hline 18 & orang & brang & $100 \%$ Akurat \\
\hline 19 & bacaan & metode & $100 \%$ Akurat \\
\hline 20 & metode & & 100 anat \\
\hline
\end{tabular}




\begin{tabular}{|c|l|l|l|}
\hline 21 & data & data & $100 \%$ Akurat \\
\hline 22 & makanan & makanan & $100 \%$ Akurat \\
\hline 23 & pengertian & pengertian & $100 \%$ Akurat \\
\hline 24 & teori & teori & $100 \%$ Akurat \\
\hline 25 & hukum & hukum & $100 \%$ Akurat \\
\hline 26 & burung & burung & $100 \%$ Akurat \\
\hline 27 & literatur & literatur & $100 \%$ Akurat \\
\hline 28 & masalah & masalah & $100 \%$ Akurat \\
\hline 29 & $\begin{array}{l}\text { perangkat } \\
\text { lunak }\end{array}$ & $\begin{array}{l}\text { perangkat } \\
\text { lunak }\end{array}$ & $100 \%$ Akurat \\
\hline 30 & kontrol & kontrol & $100 \%$ Akurat \\
\hline
\end{tabular}

Tabel 6 merupakan hasil pengujian dengan data deskripsi sebanyak 30 dari 500 data yang memiliki tingkat akurasi kecocokan sebesar $100 \%$ pada pencarian postingan menggunakan algoritma bruteforce.

\section{Membandingkan dengan Algoritma Knuth Morris Pratt dan Algoritma Horspool}

Pada algoritma knuth morris pratt dalam mencari kata dilakukan dengan pencocokan karakter jika belum cocok maka akan melakukan pergeseran sampai kata deskripsi dengan string cocok [16]. Gambar 7 merupakan langkah-langkah dalam penerapan algoritma knuth morris pratt pada pencarian string "malam".

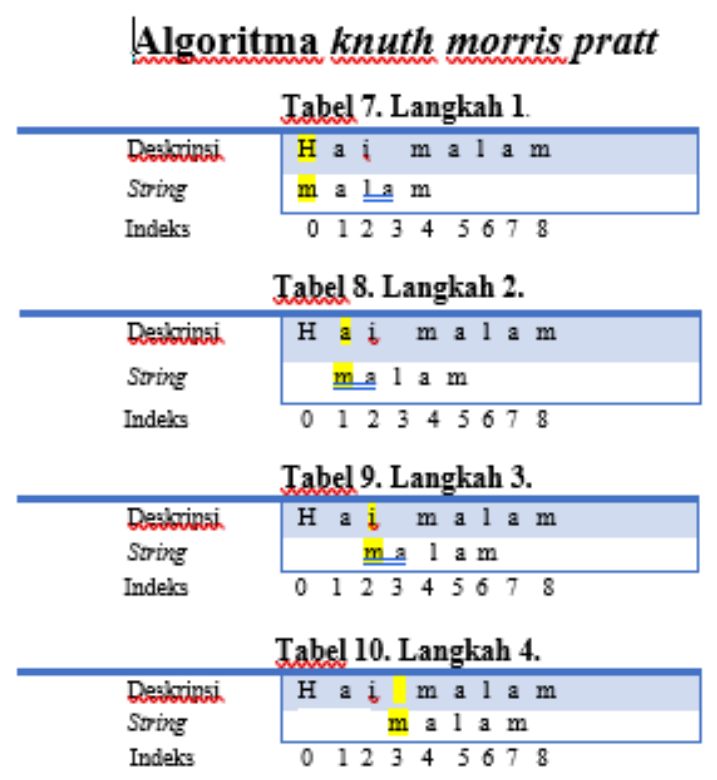

Tabel 1l. Langkah 5.

\begin{tabular}{|c|c|c|}
\hline \multirow{2}{*}{$\begin{array}{l}\text { Deabringi } \\
\text { String } \\
\text { Indeks }\end{array}$} & \multicolumn{2}{|l|}{ 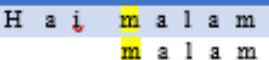 } \\
\hline & \multicolumn{2}{|l|}{$\begin{array}{lllllllll}0 & 1 & 2 & 3 & 4 & 56 & 6 & 8\end{array}$} \\
\hline \multicolumn{3}{|c|}{ Tabel 12. Langkah 6.} \\
\hline \multirow{2}{*}{$\begin{array}{l}\text { Dearoingsi } \\
\text { String }\end{array}$} & \multirow{2}{*}{\multicolumn{2}{|c|}{$\mathrm{H}$ a $\mathrm{i}$ ma $\mathrm{lam}$}} \\
\hline & & $\mathrm{m} \mathrm{a} 1$ a m \\
\hline \multirow{2}{*}{\multicolumn{3}{|c|}{ Tabel 13. Langkah 7.}} \\
\hline & & \\
\hline \multirow{2}{*}{$\begin{array}{l}\text { Deabrinsi. } \\
\text { String }\end{array}$} & \multicolumn{2}{|l|}{$\mathrm{H}$ a $\mathrm{i}$ ma $\mathrm{la} \mathrm{m}$} \\
\hline & \multicolumn{2}{|l|}{$\mathrm{m} \mathrm{a} 1 \mathrm{a} \mathrm{m}$} \\
\hline \multicolumn{3}{|c|}{$\begin{array}{llllllllll}0 & 1 & 2 & 3 & 4 & 5 & 6 & 7 & 8\end{array}$} \\
\hline \multicolumn{3}{|c|}{ Tabel 14. Langkah 8.} \\
\hline \multirow{2}{*}{$\begin{array}{l}\text { Deabrinsi. } \\
\text { String }\end{array}$} & \multicolumn{2}{|l|}{$\mathrm{H}$ a $\mathrm{i}$ ma $\mathrm{mam}$} \\
\hline & \multicolumn{2}{|l|}{$\mathrm{m} \mathrm{a} 1 \mathrm{a} \mathrm{m}$} \\
\hline
\end{tabular}

Tabel 15. Langkah 9.

\begin{tabular}{|c|c|}
\hline Dabringi & $\mathrm{Ha} \mathrm{i} \mathrm{malam}$ \\
\hline String & $\mathrm{ma} 1 \mathrm{a} \mathrm{m}$ \\
\hline
\end{tabular}

\section{Gambar 7. Implementasi Pencarian String dengan Algoritma Knuth Morris Pratt}

Pada gambar 7 menjelaskan bahwa langkah pertama melakukan pencocokan karakter pertama antara string dengan deskripsi. Bila belum menemukan kecocokan maka tetap melakukan proses pencocokan. Seperti yang terlihat pada gambar proses pencocokkan string dengan deskripsi terjadi sebanyak sembilan langkah pada Algoritma Knuth Morris Pratt. Pada langkah kesembilan antara deskripsi dengan string mengalami kecocokan di indeks ke-4 maka tidak melakukan pergeseran kembali dan informasi disimpan setelah itu tidak melanjutkan pencocokan deskripsi dengan string karena berhenti di indeks ke-8.

Pada algoritma horspool tahap pertama pencocokan string membuat nilai di tabel bad match berdasarkan karakter [17]. String malam dicocokan dengan deskripsi Hai malam. Tabel 7 merupakan nilai bad match string malam. 
Tabel 7. Bad match

\begin{tabular}{ccc}
\hline String & Indeks & Nilai \\
\hline M & 0 & 4 \\
A & 1 & 3 \\
L & 2 & 2 \\
A & 3 & 1 \\
$*$ & - & 5 \\
\hline
\end{tabular}

Pada tabel 7 nilai diperoleh dengan cara berikut.

$$
\begin{array}{ll}
\mathrm{m} & =5-0-1=4 \\
\mathrm{a} & =5-1-1=3 \\
\mathrm{l} & =5-2-1=2 \\
\mathrm{a} & =5-3-1=1
\end{array}
$$

Setelah mendapatkan nilai bad match langkah selanjutnya adalah melakukan pencocokan string. Pada gambar 8 merupakan langkah-langkah dalam penerapan algoritma Horspool pada

\begin{tabular}{|c|c|}
\hline Desabrimai. & $\mathrm{H}$ a i $\mathrm{malam}$ \\
\hline String & $\mathrm{m} a \mathrm{l}$ a $\mathrm{m}$ \\
\hline Indeks & $0 \begin{array}{lllll}0 & 1 & 2 & 3 & 4\end{array}$ \\
\hline
\end{tabular}
pencarian string "malam".

\section{Algoritma Horspool}

\begin{tabular}{|c|c|}
\hline $\begin{array}{l}\text { Deaskingi } \\
\text { String }\end{array}$ & $\begin{array}{r}\mathrm{H} \text { a } \mathrm{mal} \text { a } \mathrm{m} \\
\mathrm{mal} \text { a m }\end{array}$ \\
\hline Indeks & 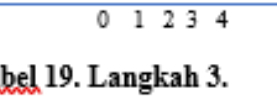 \\
\hline $\begin{array}{l}\text { Deakrinsi. } \\
\text { String }\end{array}$ & $\begin{array}{r}\mathrm{H} \text { a } \mathrm{mal} \text { a m } \\
\mathrm{mal} \text { a m }\end{array}$ \\
\hline Indeks & $\begin{array}{r}01234 \\
\text { 20. Langkah } 4 .\end{array}$ \\
\hline $\begin{array}{l}\text { Deakgrinsi. } \\
\text { String }\end{array}$ & $\begin{array}{r}\mathrm{H} \text { a } \mathrm{mal} \text { a } \\
\quad \mathrm{m} \mathrm{a} \mathrm{l} \text { a }\end{array}$ \\
\hline Indeks & $\begin{array}{lllll}0 & 1 & 2 & 3 & 4\end{array}$ \\
\hline
\end{tabular}

Tabel 17. Langkah 1.

\begin{tabular}{|c|c|}
\hline Deakcinsi. & $\mathrm{H}$ a $\mathrm{i}$ m a la $\mathrm{m}$ \\
\hline String & $\mathrm{m} \mathrm{a} 1 \mathrm{a} \mathrm{m}$ \\
\hline
\end{tabular}

Tabel 18. Langkah 2.

\begin{tabular}{|c|c|}
\hline $\begin{array}{l}\text { Deabripsi } \\
\text { String }\end{array}$ & $\begin{array}{r}\mathrm{H} \text { a } \mathrm{i} \text { ma } \mathrm{l} \text { a } \mathrm{m} \\
\mathrm{mal}\end{array}$ \\
\hline Indeks & $0 \begin{array}{lllll}0 & 1 & 2 & 3 & 4\end{array}$ \\
\hline
\end{tabular}

Tabel 2l. Langkah 5.
Tabel 22. Langkah 6.

\section{Gambar 8. Implementasi Pencarian String dengan Algoritma Horspool}

Pada gambar 8 di langkah pertama antara string dengan deskripsi mengalami kecocokan di indeks ke-4 antara $\mathrm{m}$ dan $\mathrm{m}$ maka melakukan pergeseran sebanyak 4 karena nilai $m=4$ kemudian pergeseran dilakukan pada langkah kedua. Langkah kedua pada gambar 8 antara string dengan deskripsi mengalami kecocokan di indeks ke-4 maka tidak melakukan pergeseran kembali dan informasi disimpan setelah itu melanjutkan kembali pencocokan deskripsi dengan string pada huruf sebelumnya yaitu huruf a. Proses pencocokkan terus berlangsung sampai pada langkah keenam antara deskripsi dengan string mengalami kecocokan secara keseluruhan.

\section{Hasil perbandingan}

Pada algoritma Brute Force dilakukan pencocokan string sebanyak 5 langkah, algoritma Knuth Morris Pratt sebanyak 9 langkah, dan algoritma Horspool sebanyak 6 langkah. Dalam mempersingkat waktu untuk pencarian postingan maka lebih baik menggunakan algoritma Brute Force.

\section{Pengujian}

Tahapan pengujian dengan menggunakan metode whitebox dengan menguji struktur aplikasi, flowgraph, dan flowchart. Tahapan dengan menggambarkan logika program biasa disebut dengan Flowchart sedangkan pengujian alur atau alir program disebut flowgraph. Selain membuat flowchart dan flowgraph melakukan perhitungan yaitu menghitung region dengan menghitung predicate node seperti if else flowgraph, cyclomatic complexity menghitung jumlah path dari edge dan node, terakhir independent path. 
1. Flowchart dan flowgraph Menu Awal

Flowchart dan flowgraph menu awal dapat dilihat pada gambar 9 .

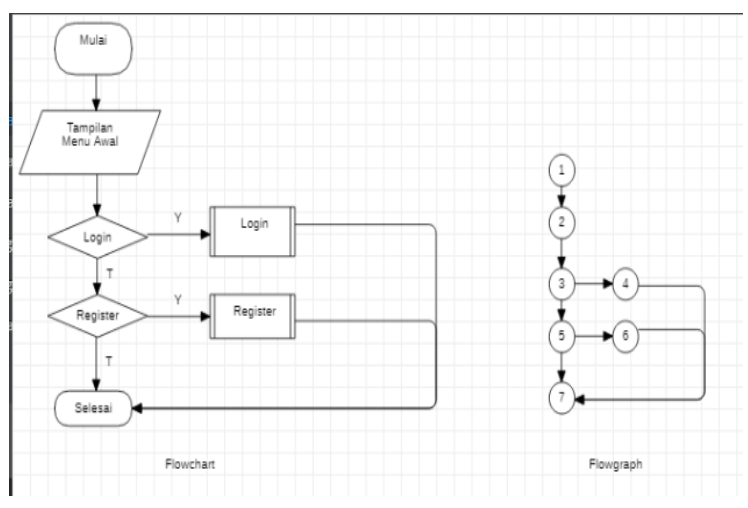

Gambar 9. Flowgraph dan flowchart menu awal

Tabel 8. Region, Cyclomatic Complexity, dan Path Flowgraph Menu Awal

\begin{tabular}{lll}
\hline Cyclomatic complexity & $\begin{array}{l}\text { Region } \\
\text { dengan } \\
\text { predicate } \\
\text { Node( })\end{array}$ & $\begin{array}{l}\text { path } \\
\text { flowgraph }\end{array}$ \\
& $\mathbf{P}=\mathbf{2}$ \\
& & \\
\hline $\mathrm{E}=8$ & $\mathrm{~V}(\mathrm{G})=\mathrm{P}$ & Path $1=1-2-3-$ \\
& +1 & $4-7$ \\
$\mathrm{~N}=7$ & $=2+1$ & Path $2=1-2-3-$ \\
& $=3$ & $5-6-7$ \\
$\mathrm{~V}(\mathrm{G})=\mathrm{E}-\mathrm{N}+2$ & $R$ & Path $3=1-2-3-$ \\
& flowgraph & $5-7$ \\
$=8-7+2$ & $=3$ & \\
& & \\
$=3$ & &
\end{tabular}

Jumlah path $=3$

2. Flowchart dan flowgraph Menu Home

Flowchart dan flowgraph menu home dapat dilihat pada gambar 10.
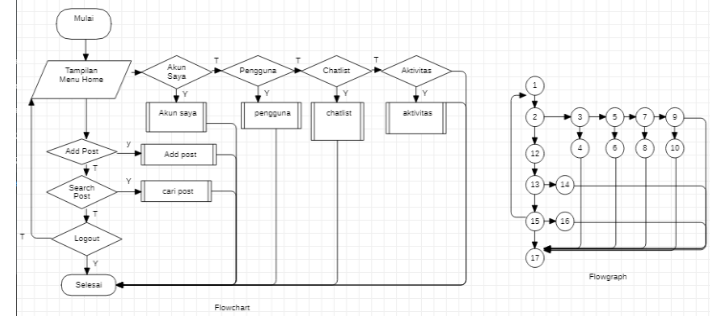
Gambar 10. Flowgraph dan flowchart menu home

Tabel 9. Cyclomatic complexity, Region, dan Path flowgraph Menu Home

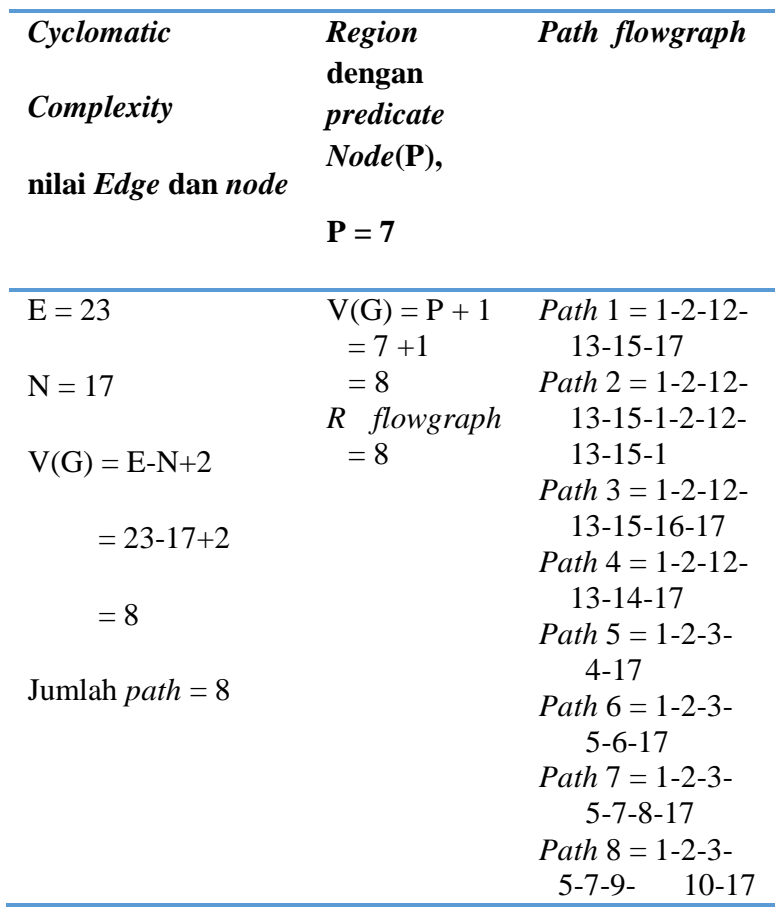

3. Flowchart dan flowgraph menu akun saya Flowgraph dan flowchart menu akun saya dapat dilihat pada gambar 11.

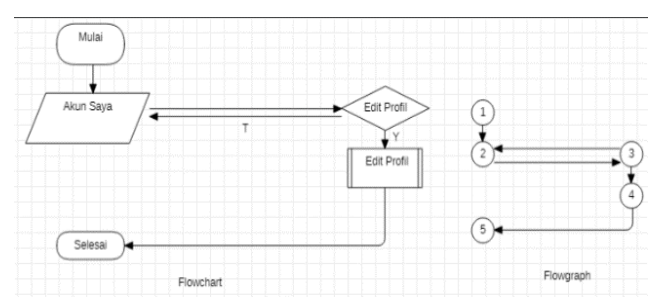

Gambar 11. Flowgraph dan Flowchart Menu Akun Saya 
Tabel 10. Cyclomatic Complexity, Region, dan Path Flowgraph menu Akun Saya

\begin{tabular}{lll}
\hline Cyclomatic & $\begin{array}{l}\text { Region dengan } \\
\text { predicate } \\
\text { Node }(\mathbf{P}),\end{array}$ & $\begin{array}{l}\text { Path } \\
\text { flowgraph }\end{array}$ \\
nilai Edge dan node & $\mathbf{P}=\mathbf{1}$ & \\
\hline $\mathrm{E}=5$ & $\mathrm{~V}(\mathrm{G})=\mathrm{P}+1$ & $\begin{array}{r}\text { Path } 1=1- \\
2-3-4-5\end{array}$ \\
& $=1+1$ & Path $2=1-$ \\
$\mathrm{N}=5$ & $=2$ & \\
& flowgraph $=$ & $2-3-4-5$ \\
$\mathrm{~V}(\mathrm{G})=\mathrm{E}-\mathrm{N}+2$ & 2 & \\
& & \\
$=5-5+2$ & & \\
$=2$ & &
\end{tabular}

Jumlah path $=2$

4. Flowchart dan flowgraph Menu Pengguna

Flowgraph dan flowchart menu pengguna dapat dilihat pada gambar 12.

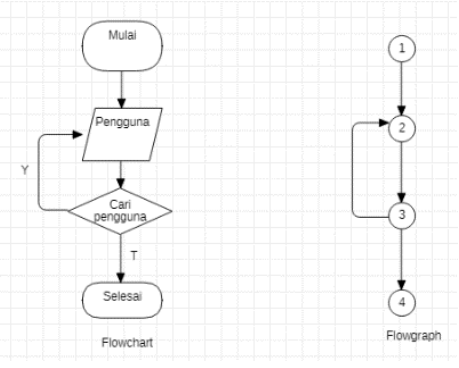

Gambar 12. Flowgraph dan flowchart menu pengguna

Tabel 11. Cyclomatic complexity, Region, dan Path flowgraph Menu Pengguna

\begin{tabular}{lll}
\hline Cyclomatic & $\begin{array}{l}\text { Region } \\
\text { dengan } \\
\text { Complexity }\end{array}$ & Path flowgraph \\
Node $(\mathbf{P})$, & \\
nilai & $\mathbf{P}=\mathbf{1}$ & \\
& & \\
\hline $\mathrm{E}=4$ & $\mathrm{~V}(\mathrm{G})=\mathrm{P}+1$ & Path $1=1-2-3-4$ \\
$\mathrm{~N}=4$ & $=1+1$ & Path $2=1-2-3-2-$ \\
& $=2$ & $3-4$ \\
& $R \quad$ flowgraph & \\
& $=2$
\end{tabular}

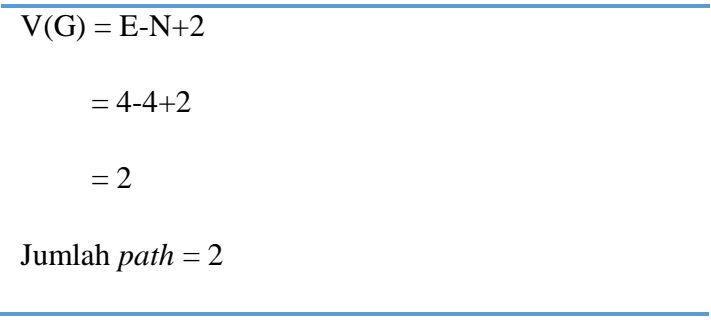

5. Flowchart dan flowgraph Menu chatlist

Flowchart dan flowgraph menu chatlist dapat dilihat pada gambar 13.
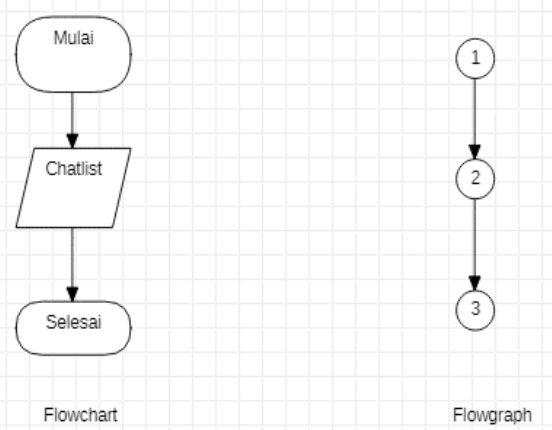

Gambar 13. Flowgraph dan flowchart menu chatlist

Tabel 12. Cyclomatic Complexity, Region, dan Path Flowgraph Menu Chatlist

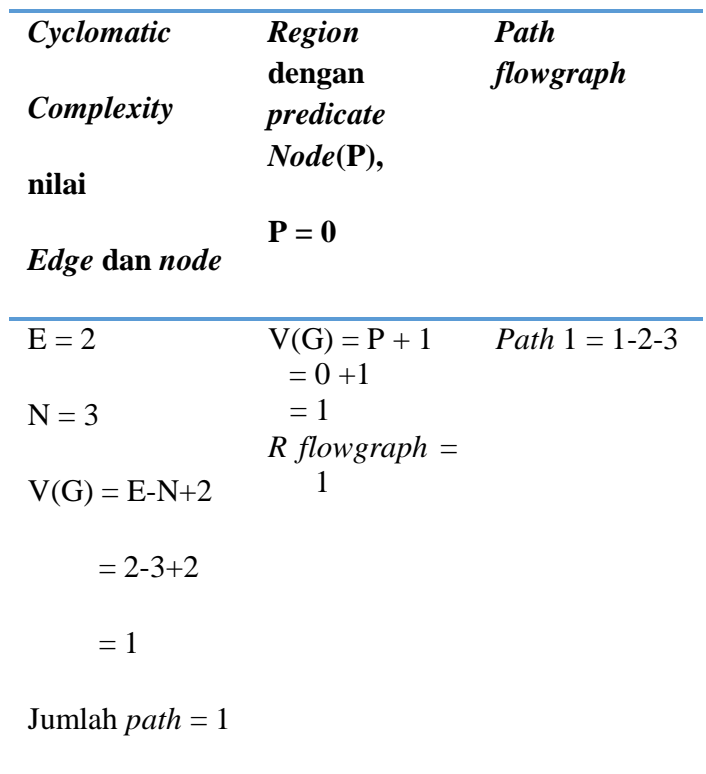


6. Flowchart dan flowgraph menu aktivitas

Flowchart dan flowgraph menu aktivitas dapat dilihat pada gambar 14.
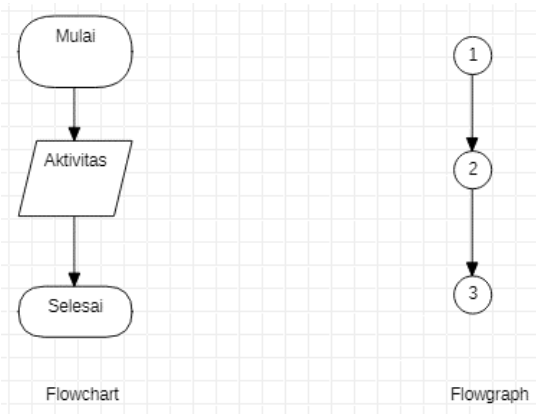

Gambar 14. Flowgraph dan Flowchart Menu Aktivitas

Tabel 13. Cyclomatic Complexity, Region, dan Path Flowgraph Menu Aktivitas

\begin{tabular}{|c|c|c|}
\hline $\begin{array}{l}\text { Cyclomatic } \\
\text { Complexity }\end{array}$ & $\begin{array}{l}\text { Region dengan } \\
\text { predicate } \\
\operatorname{Node}(\mathrm{P}),\end{array}$ & $\begin{array}{l}\text { Path } \\
\text { flowgraph }\end{array}$ \\
\hline nilai & $\mathbf{P}=\mathbf{0}$ & \\
\hline \multicolumn{3}{|l|}{ Edge dan node } \\
\hline $\mathrm{E}=2$ & $\begin{array}{l}\mathrm{V}(\mathrm{G})=\mathrm{P}+1 \\
=0+1\end{array}$ & $\begin{array}{l}\text { Path } 1=1- \\
2-3\end{array}$ \\
\hline $\mathrm{N}=3$ & $\begin{array}{l}=1 \\
R \text { flowgraph }=\end{array}$ & \\
\hline$V(G)=E-N+2$ & 1 & \\
\hline$=2-3+2$ & & \\
\hline$=1$ & & \\
\hline Jumlah path $=1$ & & \\
\hline
\end{tabular}

Tabel 14. Data Hasil Pengujian Whitebox

\begin{tabular}{lccc}
\hline Flowgraph & Cyclomatic & $\begin{array}{l}\text { Region } \\
(\mathbf{R})\end{array}$ & $\begin{array}{l}\text { Independen } \\
\text { Path }\end{array}$ \\
& $\begin{array}{l}\text { Complex } \\
\text { city }(\boldsymbol{c c})\end{array}$ & & \\
& & & \\
\hline Menu awal & 3 & 3 & 3 \\
Menu home & 8 & 8 & 8 \\
Menu akun saya & 2 & 2 & 2 \\
Menu pengguna & 2 & 2 & 2 \\
Menu chatlist & 1 & 1 & 1 \\
Menu aktivitas & 1 & 1 & 1 \\
Jumlah & 17 & 17 & 17 \\
& & &
\end{tabular}

Hasil pengujian dengan metode whitebox dapat dilihat pada tabel 14. Dengan hasil 3 parameter yang sama yaitu region, cyclomatic complexcity, dan independent path sebesar 17 maka logika serta alur program sudah sesuai dengan standar ANSI.

Tabel 15. Pengujian Perangkat

\begin{tabular}{|c|c|c|c|}
\hline Uji & $\begin{array}{c}\text { Cara } \\
\text { Pengujian } \\
\end{array}$ & $\begin{array}{c}\text { Hasil yang } \\
\text { diharapkan }\end{array}$ & $\begin{array}{c}\text { Hasil } \\
\text { pengujian }\end{array}$ \\
\hline $\begin{array}{l}\text { Menu } \\
\text { home }\end{array}$ & $\begin{array}{l}\text { Menampilkan } \\
\text { postingan }\end{array}$ & $\begin{array}{l}\text { Dapat } \\
\text { melakukan } \\
\text { pencarian } \\
\text { postsing, } \\
\text { membuat } \\
\text { postsing, } \\
\text { logout dan } \\
\text { menekan } \\
\text { menu pesan. }\end{array}$ & Berhasil \\
\hline $\begin{array}{l}\text { Menu } \\
\text { akun } \\
\text { saya }\end{array}$ & $\begin{array}{l}\text { Tombol akun } \\
\text { saya }\end{array}$ & $\begin{array}{l}\text { Menampilkan } \\
\text { informasi } \\
\text { akun } \\
\text { pengguna. }\end{array}$ & Berhasil \\
\hline $\begin{array}{l}\text { Menu } \\
\text { chatlist }\end{array}$ & $\begin{array}{l}\text { Tombol } \\
\text { chatlist }\end{array}$ & $\begin{array}{l}\text { Menampilkan } \\
\text { daftar pesan. }\end{array}$ & Berhasil \\
\hline $\begin{array}{l}\text { Menu } \\
\text { pengguna }\end{array}$ & $\begin{array}{l}\text { Tombol } \\
\text { pengguna }\end{array}$ & $\begin{array}{l}\text { Menampilkan } \\
\text { pengguna } \\
\text { yang } \\
\text { terdaftar. }\end{array}$ & Berhasil \\
\hline $\begin{array}{l}\text { Menu } \\
\text { aktivitas }\end{array}$ & $\begin{array}{l}\text { Tombol } \\
\text { aktivitas }\end{array}$ & $\begin{array}{l}\text { Menampilkan } \\
\text { notifikasi } \\
\text { komentar dan } \\
\text { like. }\end{array}$ & Berhasil \\
\hline
\end{tabular}

Pengujian menggunakan metode blackbox pada data di tabel 15 dapat dikatakan berhasil. Dengan menguji menu home, awal, chatlist, akun saya, aktivitas dan pengguna. 
Pengujian blackbox dilakukan dengan tujuan menampilkan aplikasi, cara kegunaannya serta hasilnya sesuai dengan yang diharapkan.

\section{SIMPULAN}

Aplikasi uSocial merupakan aplikasi media sosial yang dapat saling berkomunikasi satu sama lain seperti media sosial yang sudah ada sebelumnya namun bedanya pada aplikasi ini menerapkan metode RecyclerView, Firebease, Volley serta JSON yang diimplementasikan dalam mengirimkan dan menyimpan data pada saat push notification. Selain itu menggunakan penerapan algoritma Brute Force dalam pencarian string pada navigasi mencari. Pencarian dilakukan berdasarkan panjangnya kalimat dan menghasilkan akurasi sebesar $100 \%$ tepat untuk uji coba 500 data. Hasil perbandingan antara algoritma bruteforce, knuth morris pratt, dan horspool ditemukan bahwa dalam mempersingkat waktu untuk pencarian postingan maka lebih baik menggunakan algoritma Brute Force. Dalam aplikasi ini pengguna dapat melakukan posting, berkomentar, mengirim pesan, dan menyukai postingan. Dari pengujian whitebox didapatkan hasil yang sama yaitu sebesar 17 pada parameter region, cyclomatic complexcity, dan independent path maka alur serta logika program sudah sesuai dengan standar ANSI. Sedangkan hasil pada pengujian blackbox fungsi-fungsi yang ada pada aplikasi berhasil menghasilkan output yang diinginkan. Dengan menguji menu home, awal, aktivitas, pengguna, chatlist dan akun saya.

\section{DAFTAR PUSTAKA}

[1] Emmadi, Sai Spandhana Reddy, Sirisha Potluri. Android Based Instant Messaging Application Using Firebase. International Journal of Recent Technology and Engineering
(IJRTE)ISSN：2277-3878，Volume-7 Issue-5S2, January 2019.

[2] Siddik, Mohd, Akmal Nasution. Perancangan Aplikasi Push notification Berbasis Android. JURTEKSI (Jurnal Teknologi dan Sistem Informasi)ISSN 2407-1811 (print)Vol. IV No. 2, Jun 2018, hlm. $149-154$.

[3] Sabilla, Shoffi Izza, dkk. Rancang Bangun Aplikasi Perangkat Bergerak Layanan Pemesanan Barang (Studi Kasus "Dinas Kebersihan dan Pertamanan Kota Surabaya"). JURNAL TEKNIK ITS Vol. 5, No. 2, (2016) ISSN: 2337-3539 (2301-9271 Print).

[4] Tahel, Fithry. Cloud Server Dalam Pembuatan Aplikasi Fotoblog Realtime Berbasis Android. MAJALAH ILMIAH METHODA Volume 9, Nomor 2, Mei Agustus2019:64-73; ISSN:2088-9534.

[5] Li, Luqun. RTCA: Real-time Communication Application on Android Platform. International Journal of Advance Research in Computer Science and Management Studies Volume 6, Issue 4, April 2018 pg. 74-79.

[6] Rozaq, Afifur, dkk. Pembangunan Aplikasi Brawijaya Messenger dengan menggunakan Platform Firebase pada Universitas Brawijaya. Jurnal Pengembangan Teknologi Informasi dan Ilmu Komputer e-ISSN: 2548964X Vol. 2, No. 2, Februari 2018, hlm. 667-673.

[7] Halim, Rony Chandra. Penerapan Algoritma AES dalam Perancangan Aplikasi Media Sosial Berbasis Android. Jurnal ENTER Volume 1, Agustus 2018.

[8] Yapri, Albert Sanada, dkk. Rancang Bangun Aplikasi Mobile IniAtauItu Sebagai Media Tanya Jawab Berbasis 
Komunitas. JUISI, Vol. 03, No. 02, Agustus 2017.

[9] Giam, Silvy Krismayanti Winarto, dkk. Aplikasi HIMAINFRA Berbasis Android. Jurnal Infra Vol 6, No 2 2018.

[10] Opoku, Bright, dkk. Development And Implementation Of A New Android Social Media Application[Thesis]. Ghana: Department of Computer Science, Christian Service University College.

[11]N. Fatin, "Pengertian Studi Literatur." [Daring]. Tersedia pada: http://seputarpengertian.blogspot.com/ 2017/09/pengertian-studi-

literatur.html. [Diakses: 16 April 2020].

[12]Rosa, A.S. 2011. Rekayasa Perangkat Lunak. Bandung: Modula.

[13]Lanka, Surekha, dkk. Real Time Scheduler Sistem on Android Mobile App for Academic Institutions. International Journal of Engineering Trends and Technology (IJETT) Volume 25 Number 1- July 2015.

[14]Jony. 2015. Aplikasi Informasi Akademik Berbasis Android. Jurnal
SISFOKOM, Volume 04, Nomor 02, September.

[15] Sumi, A. S., Purnawansyah, P., \& Syafie, L. (2018). Analisa Penerapan Algoritma Brute Force Dalam Pencocokan String. SAKTI (Seminar Ilmu Komputer Dan Teknologi Informasi), 3(2), 88-92.

[16]Nursobah, Pajar Pahrudin, Penerapan Algoritma Pencarian Knuth-MorrisPratt (KMP) Dalam Sistem Informasi Perpustakaan SMK TI Pratama. SEBATIK 1410-3737, Vol 23 No 1 (2019): Juni 2019.

[17]Puding, Mamta Culkari, dkk. Perbandingan Algoritma Horspool dan Algoritma Raita Pada Aplikasi Istilah Psikologi Berbasis Android. semanTIK, Vol.5, No.1, Jan-Jun 2019, pp. 131-142.

[18]Inspirilo, “2200+ Kosakata Bahasa Inggris dan Artinya yang Paling Sering Digunakan" [Daring]. Tersedia pada: https://inspirilo.com/kosakatabahasa inggris/ [Diakses: 10 September 2020]. 